\title{
Quali-quantitative synthesis of the global scenario of patent families about leprosy
}

\author{
Síntese quali-quantitativa do cenário global de famílias de patentes \\ sobre hanseníase
}

Rogério Almeida Meneghin (https://orcid.org/0000-0002-3031-9827) ${ }^{1}$

${ }^{1}$ Centro de

Desenvolvimento

Tecnológico em Saúde,

Fundação Oswaldo Cruz.

Av. Brasil 4036 809A Prédio

Expansão, Manguinhos.

21040-361 Rio de Janeiro

RJ Brasil.rogerio.almeida@

cdts.fiocruz.br

\begin{abstract}
The work presents the analysis and synthesis of patent families about leprosy worldwide in the last 20 years. Three technological aspects were defined for the study of both portfolios, thus defined: diagnostic, drug/treatment and vaccine. Three thousand and three hundred twenty-three (3323) patent families were identified (790 for diagnostic, 1515 for drug and 1018 for vaccine). Fifty-eight (58) patent holders were identified and analyzed, with the most expressive portfolio of patent families, distributed in 13 countries. For the recovery of patent families, the ORBIT Intelligence ${ }^{\circledast}$ system from QUESTEL $^{\circledast}$ was used. Using quantitative and qualitative analysis and synthesis, the patterns of five strategic indicators on the global patent scenario about leprosy were observed, namely: holders of patent families; the years of filing for unionist priority for patent families; countries of unionist priority for patent families; the legal status of filed patent families; and the legal status of patent families by country of protection. It is suggested that new public policies be created to encourage synergy between patent families and the social determinants of neglected populations, in order to induce a safe path to technological independence and better performance in the fight against leprosy in the Brazil.

Key words Leprosy and patent
\end{abstract}

Resumo O trabalho apresenta a análise e a sintese de famílias de patentes sobre hanseníase em nível mundial nos últimos 20 anos. Foram definidas três vertentes tecnológicas para estudo de ambos os portfólios, assim definidas: diagnóstico, medicamento/tratamento e vacina. Identificaram-se 3.323 famílias de patentes (790 para diagnóstico, 1.515 para medicamento e 1.018 para vacina). Foram identificados e analisados 58 titulares, com mais expressivo portfólio de famílias de patentes, dispostos em 13 paises. Para a recuperação das famílias de patentes foi utilizado o sistema ORBIT Intelligence ${ }^{\oplus}$ da empresa QUESTEL ${ }^{\varpi}$. Por meio de análise e sintese quantitativa e qualitativa, observaram-se os padrões de cinco indicadores estratégicos sobre o cenário patentário mundial relativo à hanseníase, quais sejam: os titulares das famílias de patentes; os anos de depósito de prioridade unionista das famílias de patentes; os países de prioridade unionista das famílias de patentes; o status legal das famílias de patentes depositadas; e o status legal das famílias de patentes por país de proteção. Sugere-se que sejam criadas novas politicas públicas que estimulem a sinergia entre as famílias de patentes e os determinantes sociais de populações negligenciadas, no intuito de induzir um caminho seguro para independência tecnológica e melhor desempenho no combate à hanseníase no Brasil.

Palavras-chave Hanseníase e patente 


\section{Introduction}

National leprosy programmes have adopted the Global Leprosy Strategy 2016-2020: Accelerating towards a leprosy-free world and made plans that include components of the strategy adapted to their local situation. The strategy was built on three pillars: strengthen government ownership and partnerships, stop leprosy and its complications and stop discrimination and promote inclusion. Detection of leprosy early and treating patients with multidrug therapy (MDT) remain the basis of control. People affected by leprosy have participated in programmes in many countries $^{1}$.

The idea that leprosy transmission could be sustained by a mammalian reservoir in nature such as armadillos and monkeys could explain why some countries, such as Brazil, continue to register constant rate of new cases of leprosy along decades, in spite of the reduction of poverty and improved income distribution ${ }^{2}$.

Over the past 20 years, the global number of new cases of leprosy has remained stable, irrespective of available effective treatment, suggesting that better prophylactic and diagnostic tools are necessary to improve disease control and achieve reduced incidence rates; in this scenario, maintaining high therapeutic efficacy is of critical importance ${ }^{3}$.

Leprosy, a chronic infectious disease caused by Mycobacterium leprae, remains endemic in 13 low and middle-income countries worldwide. While effective and affordable multidrug therapies have the potential to cure infections, failures in detection and treatment can lead to the development of stigmatizing leprosy-associated grade-2 disabilities (G2Ds). By recent estimates, $7 \%$ of the more than 200,000 new cases of leprosy detected each year occur in individuals who have already developed grade-2 disabilities (G2Ds) by the time of diagnostic. To reduce the incidence of infection and prevent the onset of new grade-2 disabilities (G2Ds), the World Health Organization has advocated for targeted detection and intervention among higher risk groups within endemic countries. However, defining and intervening with the target groups at a subnational level remains a challenge due to a lack of understanding regarding the epidemiological risk markers of leprosy ${ }^{4}$.

While higher coverage of primary health care in Brazil was associated with higher leprosy new case detection in two studies, no associations with leprosy were found using other metrics for health care access, including: the number of general public health services, number of physicians per 1,000 inhabitants, vaccination coverage and infant mortality rates. In Brazil, an analysis of the impact of a conditional cash transfer program showed that increased coverage of the program benefits was associated with a reduction in leprosy new case detection rates ${ }^{5}$.

Leprosy remains a public health problem, even though it is a curable disease with possibility for early diagnostic and effective and free drug treatment. Brazil falls into a group called "global priority countries" for the control of the disease. Comprising 22 countries, this group detected 205,304 new cases in 2016, corresponding to $95 \%$ of the global burden of the disease. The fact that it is a clinical dermatoneuro syndrome, with potential for permanent damage, reinforces the high transcendence of leprosy, because it is also strongly related to stigma. With 25,218 notifications in 2016 and a detection rate of 12.2 cases $/ 100,000$ inhabitants, Brazil ranked second in the number of new cases reported in the world ( $11.7 \%$ of cases). For the year 2017 , an increase was observed in the number of people affected by the disease in the country, with a record of 26,875 new cases. Therefore, the persistence of leprosy in Brazil maintains the challenge for its control. Actions that favor diagnostic and treatment timely are recognized as the main strategies for control. Access to diagnostic and treatment timely reduces the suffering of the affected person and his or her Home Network (RCD), and favors the interruption of transmission, especially in areas of greater endemicity and vulnerability.

In view of this scenario, the present study was prepared according to three technological aspects of the fight against leprosy, namely: diagnostic, drug/treatment and vaccine.

\section{Methods}

The methodology was performed according to the following steps, namely:

\section{Pre-prospecting}

1) Search for the International Patent Classification (IPC) and the Cooperative Patent Classification (CPC). According to Table 1, it appears that 10 ICPs and 10 CPCs are not relevant to focus of the research (because the word "leprosy" was mandatory), and therefore were discarded. However, only one ICP retains full relevance with 
the focus of the research, and, therefore, was adopted in the creation of patent prospecting strategies. In order to optimize the pre-prospecting process, a methodological strategy dedicated (exclusive, restrictive, convergent) to the term "lep- rosy" was adopted to identify the IPC properly contextualized with the research focus. In other words, it is important to clarify that the justification for considering (search query) only one IPC (A61P 31/08) is the fact that it is the only one that

Table 1. Strategies for identifying IPC and CPC related to leprosy.

\begin{tabular}{|c|c|c|c|c|}
\hline Link & $\begin{array}{c}\text { Search } \\
\text { parameter }\end{array}$ & & Result & Conclusion \\
\hline \multirow[t]{10}{*}{$\begin{array}{l}\text { http://ipc.inpi. } \\
\text { gov.br/ipcpub }\end{array}$} & $\begin{array}{l}\text { Hanseníase; IPC } \\
\text { Hanseniasis }\end{array}$ & A61K 39/008 & $\begin{array}{l}\text { Drug compositions containing antigens } \\
\text { or antibodies (materials for immunoassay } \\
\text { G01N 33/53) [2006.01] Leishmania } \\
\text { antigens_[2006.01] }\end{array}$ & Discarded \\
\hline & & A61K 31/045 & $\begin{array}{l}\text { Drug compositions containing organic } \\
\text { active ingredients [2006.01] Hydroxy } \\
\text { compounds, e.g., alcohols; salts thereof, e.g., } \\
\text { alcoholates (hydroperoxides } \underline{\mathrm{A} 61 \mathrm{~K} 31 / 327} \text { ) } \\
\text { [2006.01] }\end{array}$ & \\
\hline & & $\begin{array}{l}\text { A } 61 \mathrm{~K} \\
31 / 4172\end{array}$ & $\begin{array}{l}\text { Drug compositions containing } \\
\text { organic active ingredients [2006.01] } \\
\text { imidazole-alkanocarboxylic acids, e.g., } \\
\text { histidine [2006.01] }\end{array}$ & \\
\hline & & A61K 31/60 & $\begin{array}{l}\text { Drug compositions containing organic } \\
\text { active ingredients [2006.01] Salicylic acid; } \\
\text { derivate thereof [2006.01] }\end{array}$ & \\
\hline & & A61K 9/51 & $\begin{array}{l}\text { Drug compositions characterized } \\
\text { by special physical forms [2006.01] } \\
\text { Nanocapsules [2006.01] }\end{array}$ & \\
\hline & Leprosy & A61K 36/185 & $\begin{array}{l}\text { Drug compositions containing } \\
\text { undetermined constitutional material } \\
\text { derived from algae, lichens, fungi or plants, } \\
\text { or derived thereof, e.g., traditional drugs } \\
\text { based on herbal [2006.01] Magnoliopsida } \\
\text { (dicotyledonous) [2006.01] }\end{array}$ & \\
\hline & & A61K 131/00 & $\begin{array}{l}\text { Indexing scheme associated with the } \\
\text { A } 61 \mathrm{~K} 36 / 00 \text { group, relating to parts of } \\
\text { plants with medicinal activity. [2006.01] } \\
\text { containing or obtained from seeds, nuts, } \\
\text { fruits or grains [2006.01] }\end{array}$ & \\
\hline & & A61K 31/00 & $\begin{array}{l}\text { Drug compositions containing organic } \\
\text { active ingredients [2006.01] }\end{array}$ & \\
\hline & & A61K 31/045 & $\begin{array}{l}\text { Drug compositions containing organic } \\
\text { active ingredients [2006.01] Hydroxy } \\
\text { compounds, e.g., alcohols; salts thereof, e.g., } \\
\text { alcoholates (hydroperoxides A61K 31/327) } \\
\text { [2006.01] }\end{array}$ & \\
\hline & & A61K 31/07 & $\begin{array}{l}\text { Drug compositions containing organic } \\
\text { active ingredients [2006.01] Retinol } \\
\text { compounds, e.g., vitamin A (retinoic acid } \\
\underline{\text { A61K } 31 / 203} \text { ) [2006.01] }\end{array}$ & \\
\hline $\begin{array}{l}\text { https://www. } \\
\text { wipo.int/ } \\
\text { classifications/ } \\
\text { ipc/ipcpub }\end{array}$ & Leprosy & A61P 31/08 & $\begin{array}{l}\text { Anti-infectives, i.e. antibiotics, } \\
\text { antiseptics, chemotherapeutics [2006.01] } \\
\text { for leprosy [2006.01] }\end{array}$ & Adopted \\
\hline
\end{tabular}


Table 1. Strategies for identifying IPC and CPC related to leprosy.

\begin{tabular}{|c|c|c|c|c|c|}
\hline Link & $\begin{array}{c}\text { Search } \\
\text { parameter }\end{array}$ & & & Result & Conclusion \\
\hline \multirow{10}{*}{$\begin{array}{l}\text { https:// } \\
\text { worldwide. } \\
\text { espacenet. } \\
\text { com/ } \\
\text { classification } \\
\text { ?locale=en_EP }\end{array}$} & \multirow[t]{10}{*}{ Leprosy } & \multirow[t]{10}{*}{$\mathrm{CPC}$} & $\mathrm{A} 61 \mathrm{~K} 31 / 00$ & $\begin{array}{l}\text { Medicinal preparations containing organic } \\
\text { active ingredients }\end{array}$ & \multirow[t]{10}{*}{ Discarded } \\
\hline & & & C07D417/00 & $\begin{array}{l}\text { Heterocyclic compounds containing two } \\
\text { or more hetero rings, at least one ring } \\
\text { having nitrogen and sulfur atoms as the } \\
\text { only ring hetero atoms, not provided for by } \\
\text { group C07D } 415 / 00\end{array}$ & \\
\hline & & & A61K9/00 & $\begin{array}{l}\text { Medicinal preparations characterized } \\
\text { by special physical form (nuclear } \\
\text { magnetic resonance contrast preparations } \\
\text { or magnetic resonance imaging } \\
\text { contrast preparations } \underline{\mathrm{A} 61 \mathrm{~K} 49 / 18} \text {; } \\
\text { preparations containing radioactive } \\
\text { substances } \underline{\mathrm{A} 61 \mathrm{~K} 51 / 12)}\end{array}$ & \\
\hline & & & C07D487/00 & $\begin{array}{l}\text { Heterocyclic compounds containing } \\
\text { nitrogen atoms as the only ring hetero } \\
\text { atoms in the condensed system, not } \\
\text { provided for by } \mathrm{C} 07 \mathrm{D} 451 / 00 \text { - } \mathrm{C} 07 \mathrm{D} 477 / 00\end{array}$ & \\
\hline & & & C07D519/00 & $\begin{array}{l}\text { Heterocyclic compounds containing } \\
\text { more than one system of two or more } \\
\text { relevant hetero rings condensed among } \\
\text { themselves or condensed with a common } \\
\text { carbocyclic ring system not provided for in } \\
\text { groups } \underline{\text { C07D } 453 / 00} \text { or } \underline{\text { C07D } 455 / 00}\end{array}$ & \\
\hline & & & $\mathrm{C} 07 \mathrm{D} 471 / 00$ & $\begin{array}{l}\text { Heterocyclic compounds containing } \\
\text { nitrogen atoms as the only ring hetero } \\
\text { atoms in the condensed system, at least } \\
\text { one ring being a six-membered ring with } \\
\text { one nitrogen atom, not provided for by } \\
\text { groups } \underline{\text { C07D451/00 }-\underline{\text { C07D } 463 / 00}}\end{array}$ & \\
\hline & & & C12Q1/00 & $\begin{array}{l}\text { Measuring or testing processes } \\
\text { involving enzymes, nucleic acids } \\
\text { or microorganisms (measuring or } \\
\text { testing apparatus with condition } \\
\text { measuring or sensing means, e.g. colony } \\
\text { counters, } \underline{\mathrm{C} 12 \mathrm{M} 1 / 34)} \text {; Compositions } \\
\text { therefor; Processes of preparing such } \\
\text { compositions }\end{array}$ & \\
\hline & & & C07D279/00 & $\begin{array}{l}\text { Heterocyclic compounds containing six- } \\
\text { membered rings having one nitrogen atom } \\
\text { and one sulfur atom as the only ring hetero } \\
\text { atoms }\end{array}$ & \\
\hline & & & Y02A50/00 & in human health protection & \\
\hline & & & C07D413/00 & $\begin{array}{l}\text { Heterocyclic compounds containing two or } \\
\text { more hetero rings, at least one ring having } \\
\text { nitrogen and oxygen atoms as the only ring } \\
\text { hetero atoms }\end{array}$ & \\
\hline
\end{tabular}

Source: own elaboration, based on the study of data retrieved from the IPC and CPC databases.

expressly presents the word "leprosy" and refers to medication for treatment of "leprosy". See Tables 1 and 2 .
2) Selection of an almost comprehensive list of strings based on keywords retrieved from the EPAB platform (https://data.epo.org/expert-ser- 
Table 2. Search strategies in the ORBIT system for leprosy.

\begin{tabular}{|c|c|c|c|c|c|}
\hline $\begin{array}{l}\text { Search } \\
\text { strategy } \\
\text { number }\end{array}$ & $\begin{array}{l}\text { Objective of } \\
\text { prospecting }\end{array}$ & $\begin{array}{c}\text { ORBIT logical expression } \\
\text { (Search strategy or search query) }\end{array}$ & $\begin{array}{l}\text { Number of } \\
\text { patent families } \\
\text { recovered } \\
\text { from the } \\
\text { ORBIT system }\end{array}$ & $\begin{array}{c}\text { Number } \\
\text { of patent } \\
\text { families } \\
\text { after manual } \\
\text { selection } \\
\end{array}$ & $\begin{array}{c}\text { Research } \\
\text { date }^{\star}\end{array}$ \\
\hline 1 & $\begin{array}{l}\text { Identify } \\
\text { technologies } \\
\text { dedicated } \\
\text { to the } \\
\text { diagnostic of } \\
\text { leprosy }\end{array}$ & $\begin{array}{l}\text { ((+HANSENIASIS+ OR +HANSENIASE+ OR } \\
\text { +LEPRO+ OR +LEPRA+ OR +LEPRE+ OR +MYCOB+ } \\
\text { LEPR+)/TI/AB/CLMS OR (+HANSEN 5D BACIL+)/ } \\
\text { TI/AB/CLMS }) \text { NOT ( (+HANSENIASPORA+ OR } \\
\text { +HANSENIASPARA+ OR +HANSENIOSPORA+ } \\
\text { OR +HANSENULA+ OR +HANSENULLA+ OR } \\
\text { +HANSENURA+ OR +HANSENUFA+ OR +HANSENII+ } \\
\text { OR +HANSENIASPORUM+ OR +LEPRAMURIUM+ } \\
\text { OR +LEPRAEMURIUM+ OR +LEPRAERNURIUM+ } \\
\text { OR +HANSENULAPOLYMORPHA+ OR +HANSEN1+ } \\
\text { OR +HANSENARLA+ OR +HANSENATLA+ } \\
\text { OR +HANSENB+ OR +HANSENCOM+ OR } \\
\text { +HANSENIELLA+ OR +HANSENEULA+ OR } \\
\text { +HANSEIASPORA+ OR +HANSANII+)/TI/AB/CLMS })) \\
\text { AND ((+DIAGNOS+ OR +DETECT+)/TI/AB/CLMS })\end{array}$ & 2.399 & 790 & 22-11-2019 \\
\hline 2 & $\begin{array}{l}\text { Identify } \\
\text { technologies } \\
\text { dedicated to } \\
\text { leprosy drug } \\
\text { / treatment }\end{array}$ & 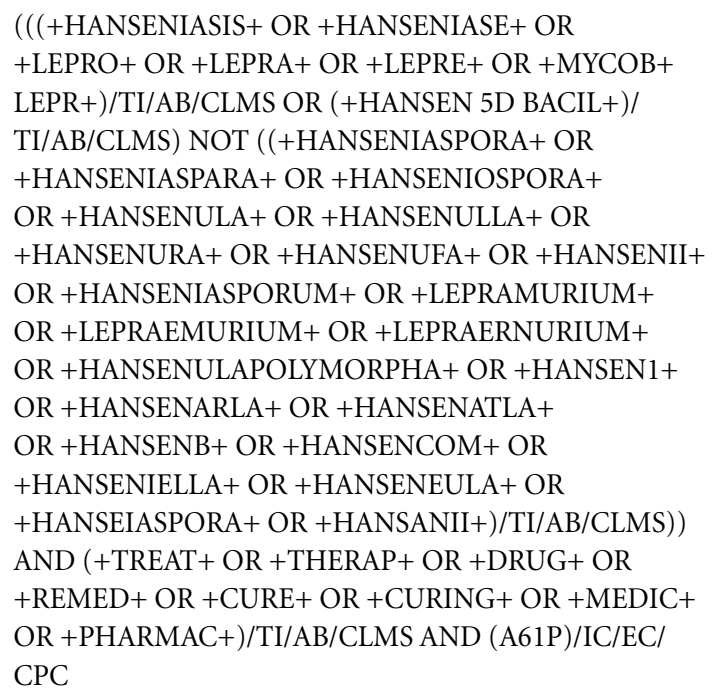 & 2.261 & 1.515 & 02-12-2019 \\
\hline 3 & $\begin{array}{l}\text { Identify } \\
\text { technologies } \\
\text { dedicated } \\
\text { to leprosy } \\
\text { vaccine }\end{array}$ & 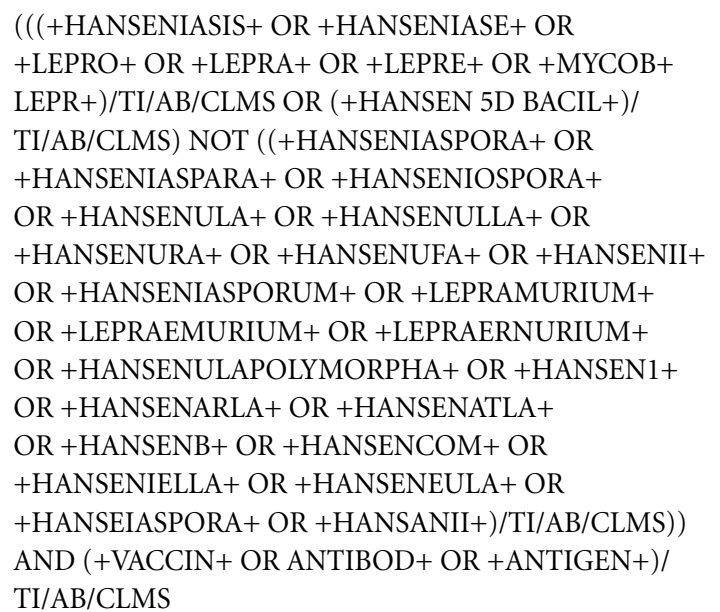 & 1.395 & 1.018 & $16-12-2019$ \\
\hline
\end{tabular}

${ }^{*}$ Note: research updated on 12/JAN/2021.

Source: own elaboration, from the study of the syntax of the ORBIT system and the EPAB platform. 
vices/index.html) in the title, abstract, description and claims fields. It is important to highlight that the current strategy aimed to overcome the usual and recurrent phenomenon of 'misspelling' in the writing of patents, in order to build a robust and optimized logical expression, according to the syntax of the ORBIT Intelligence system, in order to privilege the process of patent prospecting for technological solutions dedicated to leprosy. See Table 2.

3) Regarding the aforementioned understanding, it should be noted that a preliminary pre-prospecting of the research terms of interest in question at the following patent banks was also performed, namely: INPI-BR, EPO, USPTO, PATENTSCOPE-WIPO. See Table 2.

\section{Patent prospecting}

4) Prospecting in the patent bank: this is a patent dimension and was conducted in the ORBIT Intelligence system, from the French American company Questel. The patent document bases selected for search and retrieval were all ORBIT system patent bases, which represent more than 96 countries. It is worth pointing out that the design of search strategies, according to the ORBIT Intelligence system syntax, was based on the construction of logical expression or search query, for each of the technological aspects established in the current study, namely: diagnostic, drug/ treatment and vaccine, according to Table 2.

Regarding the first strategy, the first screening layer indicates the patent families recovered by the ORBIT system. In the second screening layer, an individual (and manual) analysis of each of the research results was performed and only those closely related to the current research were maintained. The manual verification process of all recovered patent families was completed on $29 / \mathrm{Nov} / 2019$. It is important to clarify that this process (prospecting and manual selection) was updated (redone and completed) on 12/ JAN/2021, for which the same quantitative result was obtained. In other words, all patent families identified in the prospection that were not completely relevant to the research topic were excluded from the analysis list. The refining process related to the prospection of patent families dedicated to the diagnostic of leprosy resulted in 790 patent families were maintained, which represent, after the manual filter, only $32.9 \%$ of the patent families recovered by ORBIT were maintained. It is worth explaining the process of manual verification of all patent families recovered in prospecting. In order to privilege the refinement of the ORBIT system prospecting result, each individual patent document identified in the first prospecting layer was read carefully and individually. Then, the criterion adopted for exclusion, of a certain number of patent families, from the analysis was to disregard all technological solutions (patents) that were not dedicated (specific) to leprosy in any of the three technological aspects of the study, namely: diagnostic, drug/ treatment and vaccine. In other words, despite the refined strategy of retrieving technological information, some families of recovered patents still have nothing to do with fighting leprosy, and for this reason they were considered informational noise and were excluded from the analysis.

Similarly, on the second strategy, the prospection refining process of patent families dedicated to leprosy drug/treatment resulted in 1515 patent families, and after the manual filter, only $67.0 \%$ of the patents families recovered by ORBIT were maintained.

Idem ibidem, on the third strategy, the prospection refining process of patent families dedicated to the leprosy vaccine resulted in 1018 patent families, and after the manual filter, only $73.0 \%$ of the patent families recovered by ORBIT were maintained.

\section{Results}

In Table 3, below, a consolidated profile is presented on the mass of data retrieved in the technological prospecting performed through the ORBIT system ${ }^{6}$. It is a comparative analysis between the portfolios of the three technological aspects, diagnostic, drug/treatment and vaccine, of 58 holders or institutions, and their respective countries of origin, on the world stage, prospected over 20 years.

It appears that the expressive degree of matrix sparsity (nullity of the elements) presupposes disinterest in the "pharmaceutical industry" in the development and practical implementation of new anti-leprosy technologies, since the number of holders, who do not have families of patents for diagnostic (28), drug/treatment (31) and vaccine (28) are, respectively, 48.3\%, 53.4\% and $48.3 \%$. On the other hand, the number of patent families, from all the 58 holders, regarding the technological aspects on diagnostic (248), drug/ treatment (449) and vaccine (369) are, respectively, $31.4 \%$, 29.6\% and $36.2 \%$. In summary, this fact corroborates the well-known practice of the 
Table 3. Comparative Profile of Assignee of Patent Families.

\begin{tabular}{|c|c|c|c|c|c|}
\hline \multirow[b]{2}{*}{ Assignee } & \multirow[b]{2}{*}{ Country } & \multicolumn{3}{|c|}{ Number of Patent Families } & \multirow[b]{2}{*}{ Total } \\
\hline & & Diagnostic & $\begin{array}{c}\text { Drug/ } \\
\text { Treatment }\end{array}$ & Vaccine & \\
\hline Abbvie & USA & 50 & 38 & 50 & 138 \\
\hline Immunomedics & USA & 20 & 17 & 31 & 68 \\
\hline MD Healthcare & Malaysia & 17 & 17 & 0 & 34 \\
\hline $\begin{array}{l}\text { Shandong Provincial Institute of Dermatology } \\
\text { \& Venereology }\end{array}$ & China & 16 & 0 & 0 & 16 \\
\hline University of California & USA & 14 & 12 & 21 & 47 \\
\hline Institut Pasteur & France & 10 & 0 & 13 & 23 \\
\hline Brigham \& Womens Hospital & USA & 8 & 0 & 9 & 17 \\
\hline Harvard College & USA & 7 & 0 & 11 & 18 \\
\hline Renovis & USA & 7 & 0 & 0 & 7 \\
\hline Abbott Laboratories & USA & 6 & 0 & 6 & 12 \\
\hline $\begin{array}{l}\text { CNRS - Centre National de la Recherche } \\
\text { Scientifique }\end{array}$ & France & 6 & 8 & 7 & 21 \\
\hline Rhizen Pharmaceuticals & Switzerland & 6 & 13 & 7 & 26 \\
\hline $\mathrm{SIO} 2$ & USA & 6 & 0 & 7 & 13 \\
\hline $\begin{array}{l}\text { Ajou University Industry Cooperation } \\
\text { Foundation }\end{array}$ & South Korea & 5 & 0 & 0 & 5 \\
\hline Amgen & USA & 5 & 0 & 10 & 15 \\
\hline Genentech & USA & 5 & 14 & 8 & 27 \\
\hline $\begin{array}{l}\text { INSERM - Institut National de la Sante et de la } \\
\text { Recherche Medicale }\end{array}$ & France & 5 & 11 & 13 & 29 \\
\hline Smithkline Beecham & United Kingdom & 5 & 0 & 0 & 5 \\
\hline UCB Pharma & Belgium & 5 & 0 & 6 & 11 \\
\hline US Department of Health \& Human Services & USA & 5 & 0 & 0 & 5 \\
\hline Albert Einstein College of Medicine & USA & 4 & 0 & 19 & 23 \\
\hline Alnylam Pharmaceuticals & USA & 4 & 0 & 0 & 4 \\
\hline Covidien & Ireland & 4 & 0 & 0 & 4 \\
\hline Elitra Pharmaceuticals & USA & 4 & 0 & 0 & 4 \\
\hline Hoffmann la Roche & Switzerland & 4 & 0 & 0 & 4 \\
\hline Millennium Pharmaceuticals & USA & 4 & 0 & 0 & 4 \\
\hline Schering & Germany & 4 & 0 & 6 & 10 \\
\hline University of Pennsylvania & USA & 4 & 0 & 0 & 4 \\
\hline University of Texas & USA & 4 & 0 & 0 & 4 \\
\hline Whitehead Institute for Biomedical Research & USA & 4 & 0 & 17 & 21 \\
\hline Celgene & USA & 0 & 39 & 0 & 39 \\
\hline Vertex Pharmaceuticals & USA & 0 & 36 & 0 & 36 \\
\hline Synta Pharmaceuticals & USA & 0 & 27 & 30 & 57 \\
\hline
\end{tabular}

pharmaceutical industry and of major research centers, which do not invest significantly in a solid and robust portfolio of patent families dedicated to diseases that affect neglected populations.

Another interesting aspect is the nationality of the 58 holders of patents families about leprosy identified in the present study. The percentage quantity is configured in the following propor- tion, namely: $56.9 \%$ are from the USA; $8.6 \%$ are from Germany; $6.9 \%$ are from the United Kingdom; 5.2\% are from China and Switzerland (for each of the two nations); $3.4 \%$ are from France; and $1.7 \%$ are, for each of the following seven nations, South Korea, Malaysia, Belgium, Ireland, India, Sweden, and Denmark. Still in this context of the holders' nationality, it was found that 
Table 3. Comparative Profile of Assignee of Patent Families.

\begin{tabular}{|c|c|c|c|c|c|}
\hline \multirow[b]{2}{*}{ Assignee } & \multirow[b]{2}{*}{ Country } & \multicolumn{3}{|c|}{ Number of Patent Families } & \multirow[b]{2}{*}{ Total } \\
\hline & & Diagnostic & $\begin{array}{c}\text { Drug / } \\
\text { Treatment }\end{array}$ & Vaccine & \\
\hline Merck & Germany & 0 & 52 & 11 & 63 \\
\hline Intermune & USA & 0 & 18 & 0 & 18 \\
\hline Boehringer Ingelheim International & Germany & 0 & 13 & 0 & 13 \\
\hline Pfizer & USA & 0 & 20 & 0 & 20 \\
\hline Council of Scientific \& Industrial Research & India & 0 & 11 & 0 & 11 \\
\hline Jomaa Pharmaka & Germany & 0 & 11 & 6 & 17 \\
\hline Rempex Pharmaceuticals & USA & 0 & 11 & 0 & 11 \\
\hline Vitae Pharmaceuticals & USA & 0 & 11 & 0 & 11 \\
\hline China Ocean University & China & 0 & 10 & 0 & 10 \\
\hline Swedish Orphan Biovitrum & Sweden & 0 & 10 & 0 & 10 \\
\hline Hainan University & China & 0 & 9 & 0 & 9 \\
\hline Medicines & United Kingdom & 0 & 9 & 0 & 9 \\
\hline Novartis & Switzerland & 0 & 8 & 0 & 8 \\
\hline Pharmacopeia & United Kingdom & 0 & 8 & 8 & 16 \\
\hline RQX Pharmaceuticals & USA & 0 & 8 & 0 & 8 \\
\hline Rutgers University & USA & 0 & 8 & 0 & 8 \\
\hline La Jolla Institute for Allergy \& Immunology & USA & 0 & 0 & 16 & 16 \\
\hline COM Affiliation & USA & 0 & 0 & 10 & 10 \\
\hline Curevac & Germany & 0 & 0 & 10 & 10 \\
\hline Baylor Research Institute & USA & 0 & 0 & 7 & 7 \\
\hline Statens Serum Institut & Denmark & 0 & 0 & 7 & 7 \\
\hline Oxford University Innovation & United Kingdom & 0 & 0 & 6 & 6 \\
\hline University of Tennessee Research Foundation & USA & 0 & 0 & 6 & 6 \\
\hline University of Washington & USA & 0 & 0 & 6 & 6 \\
\hline Beth Israel Deaconess Medical Center & USA & 0 & 0 & 5 & 5 \\
\hline Total & 13 countries & 248 & 449 & 369 & 1.066 \\
\hline
\end{tabular}

Source: Own elaboration, based on data from the ORBIT system.

the percentage of the portfolio of patent families from each of the nations highlighted in the present study are distributed as follows: USA with 20.7\%; Germany with 3.4\%; United Kingdom with $1.1 \%$; China with $1.0 \%$; Switzerland with $1.1 \%$; France with $2.2 \%$; South Korea with $0.2 \%$; Malaysia with $1.0 \%$; Belgium with $0.3 \%$; Ireland with $0.1 \%$; India with $0.3 \%$; Sweden with $0.3 \%$; and Denmark with $0.2 \%$.

In addition to this scenario, it is still possible to affirm the distribution of holders according to their legal nature, namely, pharmaceutical industry, university, research institute, hospital and government, with the respective percentage of participation: $56.9 \% ; 20.7 \% ; 15.5 \% ; 3.4 \%$ and $3.4 \%$. It should be noted that these same groups of legal entities have, in the same sequence, the following percentage of patent families: $22.4 \%$; $4.4 \% ; 3.7 \% ; 1.0 \%$; and $0.5 \%$.
Table 4 shows the time evolution of the "year of first unionist priority" of patent families over two decades. This concept refers to the first patent application filed in accordance with article 4 of the Paris Convention, the emblematic $\mathrm{PUC}^{7}$ of 1883. Such normative institute was incorporated into the Brazilian legal system through article 16 of Law No. 9279, dated $14^{\text {th }}$ May 1996, which "regulates industrial property rights and obligations". In short, this parameter remains on the strategic fact that demonstrates the year of beginning of intention or concrete interest in the development of a technological solution to fight leprosy, by the holders.

It should also be pointed out that each of the technological aspects, namely, diagnostic, drug/ treatment and vaccine, assemble the following amounts of patents families on leprosy: $76.7 \%$, $88.4 \%$ and $78.8 \%$, respectively. 
Table 4. Comparative Profile of First Priority Year of Patent Families.

\begin{tabular}{|c|c|c|c|c|}
\hline \multirow{2}{*}{$\begin{array}{c}\text { First } \\
\text { Priority } \\
\text { Year }\end{array}$} & \multicolumn{3}{|c|}{ Number of Patent Families } & \multirow[b]{2}{*}{ Total } \\
\hline & Diagnostic & $\begin{array}{c}\text { Drug / } \\
\text { Treatment }\end{array}$ & Vaccine & \\
\hline 1999 & 18 & 65 & 30 & 113 \\
\hline 2000 & 22 & 52 & 26 & 100 \\
\hline 2001 & 33 & 59 & 44 & 136 \\
\hline 2002 & 28 & 57 & 39 & 124 \\
\hline 2003 & 31 & 42 & 37 & 110 \\
\hline 2004 & 23 & 54 & 39 & 116 \\
\hline 2005 & 36 & 92 & 60 & 191 \\
\hline 2006 & 40 & 84 & 65 & 189 \\
\hline 2007 & 36 & 74 & 57 & 167 \\
\hline 2008 & 41 & 95 & 55 & 191 \\
\hline 2009 & 52 & 88 & 52 & 192 \\
\hline 2010 & 35 & 83 & 52 & 170 \\
\hline 2011 & 23 & 68 & 47 & 138 \\
\hline 2012 & 26 & 78 & 37 & 141 \\
\hline 2013 & 25 & 54 & 29 & 108 \\
\hline 2014 & 23 & 62 & 31 & 116 \\
\hline 2015 & 33 & 64 & 36 & 133 \\
\hline 2016 & 29 & 57 & 31 & 117 \\
\hline 2017 & 22 & 66 & 24 & 112 \\
\hline 2018 & 27 & 41 & 9 & 77 \\
\hline 2019 & 3 & 5 & 2 & 10 \\
\hline Total & 606 & 1340 & 802 & 2.751 \\
\hline
\end{tabular}

Regarding the last two years, although it is possible to attribute as a consequence to the inflections in the number of patent families required, changes in the research and development budget, in the economy or in the strategy of the holders, there is always a current information gap on patent documents due to the 18 -month ${ }^{8}$ confidentiality period and other legal deadlines inherent to the patent granting process ${ }^{9}$. In other words, in 2018 and 2019, a decrease rate is observed, which should not be considered, as in this period the patent bases have not yet been consolidated due to the confidentiality period and other legal and administrative terms ${ }^{10}$.

On the other hand, it is interesting to note the possibility that such a decrease may also represent a possible disinterest in technologies to fight leprosy, despite the increasing cases of leprosy in the world. At first, such disinterest refers to one or both aspects: the potential for therapeutic innovation in drugs/vaccines is running out, and leprosy, as a neglected disease, has lost space on the agenda of large pharmaceutical groups.

It was found that the pattern of behavior of the unionist priority dates presents more sharped inflection points and, therefore, with an oscillating general profile, combined with a decreasing general profile. In short, except for the data for the last two years, which is being consolidated due to legal and administrative deadlines, there is a tendency for a decreasing interest in filing applications for families of patents on leprosy.

Table 5 presents the geographic distribution and comparative analysis between 9 nations, from the perspective of the country of unionist priority for patents family over two decades. This indicator demonstrates the country of initiation of strategic interest in technological development to fight leprosy. In summary, the percentage of the portfolio of patent families in the countries that are a unionist priority for these intangible assets, in the technological aspects of diagnostic, drug/treatment and vaccine, are, respectively: $86.8 \% ; 91.4 \%$ and $91.5 \%$. In the scope of countries, the most expressive numbers of the patent family portfolio are USA, China, UK and Germany with the values of $63.6 \% ; 11.3 \% ; 4.9 \%$ and $3.3 \%$, respectively. In this ranking, it is interesting to note that the two countries with the highest leprosy incidence rates, India ${ }^{11}$ and Brazil ${ }^{12}$, appear in the $6^{\text {th }}$ and $8^{\text {th }}$ positions, with the proportions of $2.1 \%$ and $1.1 \%$ of the global amount of intangible property under analysis, respectively. This fact confirms the traditional lack of interest in technological solutions, via patent families, aimed at neglected populations affected by leprosy. It also appears that $22.2 \%$ of the nations are non-hegemonic and account for $2.3 \%$ of the worldwide portfolio of patent families about leprosy.

Table 6 shows the "legal status of patent families" over two decades, focusing on the technological aspects adopted in this article, namely: diagnostic, drug/treatment and vaccine. The rationale and relevance of the choice of parameters remains on the strategic fact demonstrating the degree of technological maturity and the current status of the merit processing of the intangible asset called the patent family, the pharmacological (drug) and non-pharmacological arsenal (diagnostic and vaccine) to fight leprosy.

In this study, five types of legal status of patent families were defined. It is a processing of merit. This parameter makes it possible to measure the proportion of patent families that are no longer in force, either they were revoked, expired 
or lapsed. As a rule, a portfolio of patent families with a significant percentage of inactive documents represents an indicator of the holders' lack of interest in a particular research area, and consequently, in that specific market. First, there is the number of patent families granted, which represent $41.8 \%$ of the 3323 patent families, whether for diagnostic (790), drug/treatment (1515) or vaccine (1018). Regarding the patents families that have lapsed it encloses $23.8 \%$ of them. Then, in the third position, there are pending patents families (pending), which represent $17.3 \%$. In the last positions, fourth and fifth, are the patent families revoked $(9.8 \%)$, the patent families expired (7.2\%, respectively).

It is known from the literature that, the legal scope of each patent document is territorial,

Table 5. Comparative Profile of Priority Country of Patent Families.

\begin{tabular}{lrrrr}
\hline \multirow{2}{*}{$\begin{array}{l}\text { Priority } \\
\text { Country }\end{array}$} & \multicolumn{3}{c}{ Number of Patent Families } & \\
\cline { 2 - 3 } & Diagnostic & $\begin{array}{c}\text { Drug / } \\
\text { Treatment }\end{array}$ & Vaccine & Total \\
\hline USA & 490 & 914 & 711 & 2.115 \\
China & 80 & 228 & 66 & 374 \\
United & 38 & 75 & 53 & 166 \\
Kingdom & & & & \\
Germany & 24 & 46 & 38 & 108 \\
Japan & 17 & 50 & 17 & 84 \\
India & 18 & 34 & 17 & 69 \\
Thailand & 7 & 20 & 14 & 41 \\
Brazil & 10 & 16 & 11 & 37 \\
Netherlands & 2 & 2 & 4 & 8 \\
Total & 686 & 1.385 & 931 & 3.002 \\
\hline
\end{tabular}

Source: Own elaboration, based on data from the ORBIT system.

Table 6. Comparative Profile of Legal Status of Patent Families.

\begin{tabular}{lrrrr}
\hline $\begin{array}{c}\text { Legal } \\
\text { Status of } \\
\begin{array}{c}\text { Patent } \\
\text { Families }\end{array}\end{array}$ & \multicolumn{3}{c}{ Number of Patent Families } & \\
\cline { 2 - 4 } Diagnostic & $\begin{array}{c}\text { Drug/ } \\
\text { Treatment }\end{array}$ & Vaccine & Total \\
Granted & 299 & 705 & 386 & 1.390 \\
Pending & 127 & 296 & 151 & 574 \\
Revoked & 75 & 163 & 89 & 327 \\
Expired & 75 & 76 & 89 & 240 \\
Lapsed & 214 & 275 & 303 & 792 \\
Total & 790 & 1.515 & 1.018 & 3.323 \\
\hline
\end{tabular}

Source: Own elaboration, based on data from the ORBIT system. therefore it is valid, exclusively, within the territory of a determined nation or region (for example: EPO, ARIPO, OAPI) in which it was requested or granted. It should also be clarified that the study carried out, up to this point in the work, recovered data related to the "priority country", that is, in the country of origin of the application for a certain patent. However, it is known that a particular patent can be applied for in several nations, via the Patent Cooperation Treaty (PCT) ${ }^{13}$ or by other administrative ways, so that the same protected technology in several different nations can generate a family of patents. In this way, the first deposit priority right is extended to future deposits in different nations, if it occurs up to 12 months after the first deposit, in accordance with the Paris Union Convention (PUC) ${ }^{7}$. This fact characterizes a strategic advantage of transmitting the priority date of the first deposit to all other subsequent deposits, called the unionist priority right. Given the above, in order to verify the real world scope of the "legal status" of patent families on leprosy, a new survey of the data was carried out, but now according to the concept of "protection country". In other words, a survey of "legal status" was carried out in all 32 nations in which there are families of patents, applied for and granted, on leprosy, according to Table 7.

Table 7 shows the "legal status of patent families by country of protection" over two decades, focusing on the technological aspects adopted in this article (diagnostic, drug/treatment and vaccine).

It appears that the absolute degree of matrix sparsity (nullity of all elements) in the three types of legal status, namely, revoked, expired or lapsed, presupposes the active interest of the "pharmaceutical industry" in the development and practical implementation of new technologies anti-leprosy, since the number of the other two legal statuses, granted $(91.6 \%)$ and pending $(8.4 \%)$, are significantly more expressive. It is interesting to note that there is a certain percentage balance between the technological aspects of diagnostic (D), drug/treatment (DT) or vaccine (V), in both the granted and pending portfolios. It is worth mentioning that in the granted perspective, the percentage contribution of each technological aspect is diagnostic (17.7\%), drug/ treatment $(53.1 \%)$ or vaccine $(29.2 \%)$. Similarly, in the pending perspective, the percentages are diagnostic $(20.5 \%)$, drug/treatment $(52.7 \%)$ or vaccine $(26.7 \%)$. In summary, it can be said that there is a clear performance of "market reserve", as $69 \%$ of countries are hegemonic nations. In the case of Brazil, it is interesting to note that the 
Table 7. Comparative Profile of Legal Status of Patent Families by Protection Country.

\begin{tabular}{|c|c|c|c|c|c|c|c|c|c|c|c|c|c|c|c|c|}
\hline \multirow{4}{*}{ Protection Country } & \multirow{2}{*}{\multicolumn{15}{|c|}{$\begin{array}{l}\text { Number of Patent Families by legal status and technology type (D, DT, } \\
\text { V) }\end{array}$}} & \multirow{4}{*}{$\begin{array}{l}\text { Total by } \\
\text { country }\end{array}$} \\
\hline & & & & & & & & & & & & & & & & \\
\hline & \multicolumn{3}{|c|}{ Granted } & \multicolumn{3}{|c|}{ Pending } & \multicolumn{3}{|c|}{ Revoked } & \multicolumn{3}{|c|}{ Expired } & \multicolumn{3}{|c|}{ Lapsed } & \\
\hline & D & DT & $\mathbf{V}$ & $\mathrm{D}$ & DT & $\mathrm{V}$ & $\mathrm{D}$ & DT & $\mathrm{V}$ & $\mathrm{D}$ & DT & $\mathrm{V}$ & $\mathrm{D}$ & DT & $\mathrm{V}$ & \\
\hline USA & 186 & 466 & 271 & 27 & 57 & 41 & 0 & 0 & 0 & 0 & 0 & 0 & 0 & 0 & 0 & 1.048 \\
\hline $\mathrm{EPO}^{(\mathrm{i})}$ & 118 & 377 & 195 & 31 & 74 & 45 & 0 & 0 & 0 & 0 & 0 & 0 & 0 & 0 & 0 & 840 \\
\hline China & 98 & 280 & 140 & 29 & 75 & 24 & 0 & 0 & 0 & 0 & 0 & 0 & 0 & 0 & 0 & 646 \\
\hline India & 91 & 272 & 150 & 17 & 29 & 20 & 0 & 0 & 0 & 0 & 0 & 0 & 0 & 0 & 0 & 579 \\
\hline Japan & 98 & 319 & 158 & 19 & 51 & 28 & 0 & 0 & 0 & 0 & 0 & 0 & 0 & 0 & 0 & 673 \\
\hline Canada & 77 & 262 & 137 & 14 & 34 & 16 & 0 & 0 & 0 & 0 & 0 & 0 & 0 & 0 & 0 & 540 \\
\hline Germany & 88 & 273 & 149 & 1 & 1 & 1 & 0 & 0 & 0 & 0 & 0 & 0 & 0 & 0 & 0 & 513 \\
\hline Australia & 72 & 233 & 130 & 11 & 29 & 12 & 0 & 0 & 0 & 0 & 0 & 0 & 0 & 0 & 0 & 487 \\
\hline United Kingdom & 83 & 263 & 146 & 0 & 1 & 1 & 0 & 0 & 0 & 0 & 0 & 0 & 0 & 0 & 0 & 494 \\
\hline Singapore & 70 & 195 & 111 & 13 & 25 & 11 & 0 & 0 & 0 & 0 & 0 & 0 & 0 & 0 & 0 & 425 \\
\hline France & 80 & 253 & 130 & 0 & 1 & 1 & 0 & 0 & 0 & 0 & 0 & 0 & 0 & 0 & 0 & 465 \\
\hline Mexico & 73 & 271 & 142 & 6 & 27 & 7 & 0 & 0 & 0 & 0 & 0 & 0 & 0 & 0 & 0 & 526 \\
\hline Republic of Korea & 61 & 189 & 106 & 7 & 24 & 10 & 0 & 0 & 0 & 0 & 0 & 0 & 0 & 0 & 0 & 397 \\
\hline Switzerland & 66 & 186 & 109 & 0 & 0 & 0 & 0 & 0 & 0 & 0 & 0 & 0 & 0 & 0 & 0 & 361 \\
\hline South Africa & 63 & 222 & 98 & 0 & 2 & 1 & 0 & 0 & 0 & 0 & 0 & 0 & 0 & 0 & 0 & 386 \\
\hline Spain & 57 & 185 & 89 & 0 & 0 & 0 & 0 & 0 & 0 & 0 & 0 & 0 & 0 & 0 & 0 & 331 \\
\hline Hong Kong (China) & 55 & 165 & 84 & 1 & 4 & 3 & 0 & 0 & 0 & 0 & 0 & 0 & 0 & 0 & 0 & 312 \\
\hline Italy & 56 & 181 & 89 & 0 & 1 & 0 & 0 & 0 & 0 & 0 & 0 & 0 & 0 & 0 & 0 & 327 \\
\hline Ireland & 54 & 150 & 96 & 0 & 0 & 0 & 0 & 0 & 0 & 0 & 0 & 0 & 0 & 0 & 0 & 300 \\
\hline Taiwan & 42 & 122 & 68 & 12 & 41 & 27 & 0 & 0 & 0 & 0 & 0 & 0 & 0 & 0 & 0 & 312 \\
\hline Israel & 42 & 138 & 76 & 7 & 21 & 9 & 0 & 0 & 0 & 0 & 0 & 0 & 0 & 0 & 0 & 293 \\
\hline Netherlands & 48 & 125 & 80 & 0 & 0 & 0 & 0 & 0 & 0 & 0 & 0 & 0 & 0 & 0 & 0 & 253 \\
\hline Philippines & 44 & 113 & 65 & 3 & 9 & 4 & 0 & 0 & 0 & 0 & 0 & 0 & 0 & 0 & 0 & 238 \\
\hline New Zealand & 40 & 131 & 66 & 5 & 9 & 5 & 0 & 0 & 0 & 0 & 0 & 0 & 0 & 0 & 0 & 256 \\
\hline Austria & 43 & 0 & 70 & 0 & 0 & 0 & 0 & 0 & 0 & 0 & 0 & 0 & 0 & 0 & 0 & 113 \\
\hline Belgium & 39 & 0 & 63 & 0 & 0 & 0 & 0 & 0 & 0 & 0 & 0 & 0 & 0 & 0 & 0 & 102 \\
\hline Sweden & 39 & 109 & 65 & 0 & 0 & 0 & 0 & 0 & 0 & 0 & 0 & 0 & 0 & 0 & 0 & 213 \\
\hline Brazil & 31 & 131 & 66 & 7 & 23 & 10 & 0 & 0 & 0 & 0 & 0 & 0 & 0 & 0 & 0 & 268 \\
\hline Colombia & 36 & 102 & 0 & 2 & 6 & 0 & 0 & 0 & 0 & 0 & 0 & 0 & 0 & 0 & 0 & 146 \\
\hline Denmark & 38 & 0 & 66 & 0 & 0 & 0 & 0 & 0 & 0 & 0 & 0 & 0 & 0 & 0 & 0 & 104 \\
\hline Portugal & 0 & 129 & 64 & 0 & 0 & 0 & 0 & 0 & 0 & 0 & 0 & 0 & 0 & 0 & 0 & 193 \\
\hline Turkey & 0 & 110 & 0 & 0 & 0 & 0 & 0 & 0 & 0 & 0 & 0 & 0 & 0 & 0 & 0 & 110 \\
\hline Total by technology & 1988 & 5.952 & 3279 & 212 & 544 & 276 & 0 & 0 & 0 & 0 & 0 & 0 & 0 & 0 & 0 & 12.251 \\
\hline Total by legal status & & 11.219 & & & 1.032 & & & 0 & & & 0 & & & 0 & & 12.251 \\
\hline
\end{tabular}

Note 1: technology type code 0 D: Diagnostic; DT: Drug/Treatment; V: Vaccine.

Note 2: Superscript index (i) refers to a regional patent office; the rest are national patent offices.

Source: Own elaboration, based on data from the ORBIT system.

portfolio of family of patents on leprosy is quite tasteless compared to the global number, which demonstrates a mismatch of public policies in the sector, since the country ranks second in the world ranking of cases of leprosy. The percentage of patent portfolios in legal status granted and pending are, respectively diagnostic (1.6\%), drug/treatment $(2.2 \%)$, vaccine $(2 \%)$; and diagnostic $(3.3 \%)$, drug/treatment $(4.2 \%)$, vaccine
(3.6\%). Also noteworthy is the fact that Brazil is the destination of only $2.2 \%$ of the total number of patent families on leprosy in the world. Another interesting aspect is that the ORBIT system reserves a prominent position for the city of Hong Kong, as it, despite belonging to China, is considered a special administrative region with its own legal system, among other administrative, normative and cultural aspects. 


\section{Discussion}

The results previously presented indicate that, despite the methodological approach adopted, with significant geo-historic process scope, the data retrieved from patent prospecting for leprosy, denote a significant lack of interest and sparsity (low density of non-null elements), among the holders, in the search for technological solutions dedicated to combat Hansen's bacillus.

The general quantitative mapped was 3323 patent families, with $790(23.8 \%)$ on diagnostic, 1515 (45.6\%) on drug/treatment and 1018 (30.6\%) on vaccine. In addition to 58 institutions distributed in 13 nations, over 20 years, and in the procedural scope with five legal statuses on patent families.

The significant degree of matrix sparsity (nullity of the elements) of the holders, since they do not have patent families, presents a percentage with technical tie between the three technological aspects adopted (diagnostic, drug/ treatment and vaccine), the values being, respectively, $48.3 \%, 53.4 \%$ and $48.3 \%$. Allied to this fact, another important aspect shows that the effective percentage of patent families, for the aforementioned technological aspects, presents values, relatively little expressive, since they are, respectively, $31.4 \%, 29.6 \%$ and $36.2 \%$.

Regarding the combination of technological aspects, another indicator stood out, that is: the percentage of the binomial holder-patents family. The combinations are " diagnostic + drug + vaccine", " diagnostic + drug", " diagnostic + vaccine", "drug + vaccine", " diagnostic", "drug", "vaccine", and their respective values are: $12.1 \%$ $10.7 \%$; 1.7\%-1.0\%; 17.2\%-4.9\%; 6.9\%-4.6\%; 20.7\%-2.0\%; $25.9 \%-6.7 \%$; $15.5 \%-2.2 \%$. Thus, it is noted that the significant majority of the holders are dedicated to the technological aspect "drug" (25.9\%), and the most expressive portfolio is the one of patent families on " diagnostic + drug + vaccine" (10.7\%), and regarding "drug" (6.7\%).

It appears that the nationality of the 58 holders of patents families about leprosy is configured in the following proportion, which is: $56.9 \%$ are from the USA; $8.6 \%$ are from Germany; $6.9 \%$ are from the United Kingdom; 5.2\% are from China; $5.2 \%$ are from Switzerland; $3.4 \%$ are from France; and $1.7 \%$ belong to each of the following seven nations: South Korea, Malaysia, Belgium, Ireland, India, Sweden, Denmark. It was also found that the distribution of the percentage of the portfolio of patent families is: USA with
20.7\%; Germany with 3.4\%; United Kingdom with $1.1 \%$; China with $1.0 \%$; Switzerland with $1.1 \%$; France with $2.2 \%$; South Korea with $0.2 \%$; Malaysia with $1.0 \%$; Belgium with $0.3 \%$; Ireland with $0.1 \%$; India with $0.3 \%$; Sweden with $0.3 \%$; and Denmark with $0.2 \%$. The legal nature of the holders is shown by: pharmaceutical industry, university, research institute, hospital and government, with respective percentage of participation being: $56.9 \% ; 20.7 \% ; 15.5 \% ; 3.4 \%$ and $3.4 \%$. In this same perspective, these groups of legal entities have, in the same sequence, the percentage values of patent families are: $22.4 \% ; 4.4 \% ; 3.7 \%$; $1.0 \%$; and $0.5 \%$.

In the context of the historic evolution mapped by the "year of first unionist priority" of patent families, the technological aspects, diagnostic, drug/treatment and vaccine, account for $76.7 \%, 88.4 \%$ and $78.8 \%$, respectively, of patent families about leprosy. Such indicator demonstrates the year of beginning of concrete interest in the development of a technological solution to fight leprosy, by the holders. In the years 2018 and 2019, a decrease rate is observed, since in this period the patent bases have not yet been consolidated due to the confidentiality period and other legal and administrative terms. Concomitantly, such a decrease can also represent a possible lack of interest in technologies to fight leprosy, despite the growing cases of leprosy in the world, due to the exhaustion of the potential for therapeutic innovation of drugs/vaccines, and leprosy, an emblematic malaise of neglected populations, has lost space on the agenda of large pharmaceutical groups. The panorama of unionist priority dates presents more sharped inflection points, which characterizes a general oscillating and decreasing profile, which demonstrates the tendency of a decreasing interest in filing applications for patent families for leprosy.

The geographical distribution of the indicator "country of unionist priority" of the patents families about leprosy is mapped by 9 nations, and shows the first countries with strategic interest in technological development to fight leprosy. It was found that the percentage of the portfolio of patent families in these priority countries, considering the technological aspects of diagnostic, drugs/treatment and vaccine are, respectively: $86.8 \% ; 91.4 \%$ and $91.5 \%$. In this same perspective, the nations with the most expressive percentages of the patent family portfolio are USA, China, UK and Germany with 63.6\%; 11.3\%; $4.9 \%$ and $3.3 \%$, respectively. In addition to India and Brazil, which are nations with the worst 
leprosy epidemiological rates, in the $6^{\text {th }}$ and $8^{\text {th }}$ positions, with the proportions of $2.1 \%$ and $1.1 \%$ of the global amount of intangible property under analysis, respectively. It was found that $22.2 \%$ of nations are non-hegemonic and account for $2.3 \%$ of the global portfolio of patent families on leprosy.

In this study, five types of legal status of patent families were defined. It is a processing of merit. This parameter makes it possible to measure the proportion of patent families that are no longer in force (revoked, expired or lapsed), technological maturity and the current status of processing the merit of the intangible property called the patent family, the pharmacological (drug) and non-pharmacological (diagnostic and vaccine) arsenal to fight leprosy. The number of granted patent families, account for $41.8 \%$ of the 3323 patent families, whether for diagnostic (790), drug/treatment (1515) or vaccine (1018). The patent families that have terminated are $23.8 \%$ of the patent families. Another group is pending patent families, which represent $17.3 \%$. In the last positions are the patent families revoked with $9.8 \%$, the patent families expired with $7.2 \%$, respectively. It is interesting to note that $40.8 \%$ of patent families are inactive documents (revoked, expired or lapsed), which means a significant percentage of lack of interest from the holders in the research, and consequently, in this specific market to fight leprosy.

It is interesting to note that, there was an increase of $246.2 \%$ in the geographical scope of patent protection, when comparing the countries of unionist priority with the countries of protection. However, in the geographical perspective of countries of protection, such expansion of the portfolio of patent families on leprosy focuses only on the legal status of granted patent $(91.6 \%)$ and patent pending $(8.4 \%)$. It also appears that both portfolios have the same quantitative standard, whose ranking is drug/treatment (granted: $53.1 \%$; pending: $52.8 \%$ ), vaccine (granted: 29.2\%; pending: $26.7 \%$ ) and diagnostic (granted: 17.7\%; pending: $20.5 \%$ ). Also noteworthy are the nations with the most significant percentage of patent families by country of protection, namely: USA (8.6\%), EPO (6.9\%), Japan (5.5\%), China $(5.3 \%)$ and India $(4.7 \%)$. In this perspective of legal status by country of protection, it is worth mentioning that the two countries with the highest worldwide incidence rate of leprosy, India ${ }^{11}$ and Brazil ${ }^{12}$, occupy, respectively, the $5^{\text {th }}(4.7 \%)$ and $24^{\text {th }}(2.2 \%)$ positions in the quantitative ranking of patent families.
However, within the scope of the legal status on patent families, it was identified that $40.8 \%$ of the portfolio is inactive. It is interesting to note that this is a significant portion of technologies that are Freedom to Operate (FTO) or in the public domain, which no longer have exclusivity for commercial exploitation in favor of their respective holders. Such finding can be a strategic element to improve public policies for universal access to pharmacological (drug/treatment) and non-pharmacological (diagnostic and vaccine) technologies.

However, it is important to mention that even in the case of granted patents, there are policy options that can be adopted, such as the research exception. In this context, the "Bolar Exception" strategy should be highlighted. In general, it all started with a legal process made by Roche Products against Bolar Pharmaceutical Co. Bolar Pharmaceutical Co. was a generic medicines manufacturer which initiated researches with the active ingredient used in Roche's Dalmane $^{\circledast}$ (flurazepam), which was protected by patent. Because Bolar initiated this investigation prior to Roche's patent expiration to determine whether its generic product was bioequivalent to Dalmane, Roche sued it for patent infringement. Bolar claimed that it used experimentally, which was not accepted by the Court of Appeals for the Federal Circuit because Bolar aimed at selling the generic product, so the use was, in fact, commercial. The Court of Appeals also claimed that the decision on the possibility of exploiting a patent before its expiration to allow the generic drugs manufacturing after the expiring of its patent should have been decided by the Congress, not by Court. Shortly thereafter, the Hatch-Waxman Act (Law No. 98-417) emerged, which established the current system for approving generic drugs by the FDA (Food and Drug Administration). Thus, after this new law, the U.S. legal order began to allow research and development of a drug before its patent expires. This fact stimulated pharmaceutical companies dedicated to the production of generic drugs and allowed such drugs to be readily marketed as soon as the patent ceased to take effect ${ }^{14,15}$. It should be clarified that the Bolar exception was incorporated in Brazilian legislation by Law No. 10.196/2001 ${ }^{16}$, which added section VII of Article 43 of Law No. 9.279/96.

It is also important to note that there are other possibilities for universal access to medicines with patent granted, such as: Tiered prices strategy, Kaletra Global initiative, Medicines Patent Pool initiative (MPP), Global Alliance for 
Vaccines and Immunizations initiative (GAVI), Evergreening combat, Pipeline patents monitoring (also known as the revalidation patent, arising from the flexibilities allowed by TRIPS-plus), TRIPS-plus advantages and limitations, Compulsory license threat, ADI possibility (ADIn No 4234 - Unconstitutionality Direct Action demand by Fenafar and PGR against the pipeline, towards the STF - Supreme Court - pending decision), Priority examination programs, The Patent Information Initiative Platform for Medicines (Pat-Informed), The Accessibsa Initiative (project called "Innovation and Access to Medicines in India, Brazil and South Africa") it aims to expand access to medicines to treat patients with significant socioeconomic vulnerability ${ }^{17}$.

In this scenario, the pattern already identified is also confirmed, whereby the technological aspect of "drug/treatment" presents the most expressive portfolio, which represents $45.6 \%$ of the total value of patent families about leprosy, which in summary demonstrates a concentration of interest and institutional effort of the holders and inventors focused on pharmacological patents.

In this sense, it is known that investigating and monitoring the patent family portfolio is an expressive challenge, both for the qualitative and quantitative aspect, as well as for the dynamics of expanding the scope of territorial protection of patent families. Therefore, in order to privilege the mechanisms of analysis and synthesis, of the scenarios of patent families of the present study, an exhaustive list of all "WO parent publication number" on the three technological aspects, diagnostic, drug/treatment and vaccine, to fight leprosy. This list is available in the permanent link: http://bit.ly/35GGjWv.

The above-mentioned facts confirm the traditional lack of interest in technological solutions, via patent families, aimed at neglected populations affected by leprosy, which presupposes lack of interest in the "pharmaceutical industry" and "research units" in the development and practical implementation of new anti-leprosy technologies, in favor of neglected populations.

\section{Conclusion}

The obtained data shows a world scenario on leprosy patent families that indicates the necessity of urgent undertaking efforts towards new public policies that can better answer such demands. More specifically regarding the Brazilian situation, it is important to highlight the need to monitor legal aspects concerning patents, such as patent filing issues in Resolution INPI No. 239 ${ }^{18}$, especially in article 3 , item IX, article 12 , paragraph 2, and Annex II, item 6, that "regulates the priority procedure of patent filings under DIRPA".

It is also important to register all efforts around Law No. $9279^{19}$, which "regulates rights and obligations related to industrial property", in order to improve the patent system in the country, by means of a promotion that privileges the increase of "Brazilian priority" of patent portfolio, consonant to INPI Resolution No. $237^{20}$, to increase the number of patents granted to nationals, decrease the average time for granting patents in Brazil, in accordance with INPI Resolution No. $240^{21}$ and INPI Resolution No. 241 (backlog $)^{22}$. In summary, it is understood that the synergistic combination of the effects (social, economic and legal) of these two legal diplomas can significantly impact Brazil's technological independence in the context of the creation of new technologies to fight leprosy.

The general overview of struggling leprosy, in two decades, has 3323 patent families, 790 (23.8\%) on diagnostic, 1515 (45.6\%) on drug/ treatment and $1018(30.6 \%)$ on vaccine. Such a patent ecosystem has 58 holders spread across 13 nations, with 5 legal statuses on patent families.

It is concluded that the global patent scenario for the fight against leprosy is vulnerable and lacks immediate dedicated public policies, due to the high degree of sparsity of the holders, in the technological aspects adopted, $48.3 \%, 53.4 \%$ and $48.3 \%$, added, similarly, to the low value of effective portfolios, $31.4 \%, 29.6 \%$ and $36.2 \%$ of effective portfolios.

The historical curve on unionist priority dates has a general oscillating and decreasing profile, which demonstrates the tendency of a decreasing interest in filing applications for patent families about leprosy.

In the geography of the countries with unionism priority, the fact that India and Brazil, with the most challenging epidemiological leprosy scenarios, together account for $3.2 \%$ of the global amount of intangible property under analysis; and $22.2 \%$ of the nations are non-hegemonic and account for $2.3 \%$ of the worldwide portfolio of patent families on leprosy. The geographical scope of patent protection expanded $246.2 \%$, from countries of unionist priority (origin) to countries of protection (destination). On the other hand, on the legal status by country of 
protection India and Brazil together account for $6.9 \%$ of the number of patent families.

Regarding the legal status on patent families, it was identified that $40.8 \%$ of the portfolio are inactive processes, that is, free to operate technologies (FTO - Freedom to Operate) available for free commercial exploitation. This fact makes it possible to improve public policies for universal access to pharmacological/corrective (drug/treatment) and non-pharmacological/preventive (diagnostic and vaccine) technologies. It was also found that the technological aspect of "drug/treatment" has the most expressive portfolio, which represents $45.6 \%$ of the total value of patent families on leprosy, which in summa- ry demonstrates a concentration of interest and institutional effort by the holders and inventors focused on pharmacological patents, which in summary, have the "corrective" profile.

It is observed that, the most appropriate would be, the "preventive" technological aspects, that is, "diagnostic" and "vaccine" should receive the due promotion, application and contextualization with the social determinants, in order to reduce the indices and the damages caused due to the consequences of late diagnoses, discontinuation of treatment and the lack of universal access to health care, in favor of neglected populations affected by leprosy.

\section{Acknowledgements}

The author thanks the institutional and financial support received from: Coordenação de Aperfeiçoamento de Pessoal de Nível Superior (CAPES), Fundação Oswaldo Cruz (FIOCRUZ), Centro de Desenvolvimento Tecnológico em Saúde (CDTS) and Escritório de Inovação (EI). I dedicate this work to my friend, Mr. Paulo Xavier de Matos Belém, for the victory over the theme of this work.

\section{Funding}

This work was supported by the CAPES-FIOCRUZ-CDTS Agreement. 


\section{References}

1. Global leprosy update, 2018: moving towards a leprosy free world, p. 389. Wkly Epidemiol Rec 2019; 94(35/36): 389-412. [cited $2020 \mathrm{Feb} 3$ ]. Available from: https://apps.who.int/iris/bitstream/handle/106 65/326775/WER9435-36-en-fr.pdf?ua=1

2. Neumann AS, Dias FA, Ferreira JS, Fontes ANB, Rosa PS, Macedo RE, Oliveira JH, Teixeira RLF, Pessolani MCV, Moraes MO, Suffys PN, Oliveira PL, Sorgine MHF, Lara FA. Experimental Infection of Rhodnius prolixus (Hemiptera, Triatominae) with Mycobacterium leprae Indicates Potential for Leprosy Transmission, p. 2. PLoS ONE 2016; 11(5):e0156037. [cited 2020 Feb 4]. Available from: https://doi.org/10.1371/ journal.pone.0156037.

3. Rosa OS, D'Espindula HRS, Melo ACL, Fontes ANB, Finardi AJ, Belone AFF, Sartori BGC, Pires CAA, Soares CT, Marques FB, Branco FJD, Baptista IMFD, Trino LM, Fachin LRV, Xavier MB, Floriano MC, Ura S, Diório SM, Delanina WFB, Moraes MO, Virmond MCL, Suffys PN, Mira MT. Emergence and Transmission of Drug-/Multidrug-resistant Mycobacterium leprae in a Former Leprosy Colony in the Brazilian Amazon, p. 1. Clin Infect Dis 2020; 70(10):2054-2061.

4. Pescarini JM, Strina A, Nery JS, Skalinski LM, Andrade KVF, Penna MLF, Brickley EB, Rodrigues LC, Barreto ML, Penna GO. Socioeconomic risk markers of leprosy in high-burden countries: a systematic review and meta-analysis. PLoS Negl Trop Dis 2018; 12(7): e0006622.

5. Pescarini JM, Strina A, Nery JS, Skalinski LM, Andrade KVF, Penna MLF, Brickley EB, Rodrigues LC, Barreto ML, Penna GO. (2018) Socioeconomic risk markers of leprosy in high-burden countries: A systematic review and meta-analysis. PLoS Negl Trop Dis 2018; 12(7):e0006622.

6. ORBIT. ORBIT Intelligence System. Questel Company. France, 2020. [cited 2020 Jan 9]. Available from: https://www.orbit.com/.

7. FRANCE. Paris Union Convention (PUC), de 20 de março de 1883. [cited 2020 Feb 19]. Available from: http://www.inpi.gov.br/legislacao-1/cup.pdf

8. Marques RSMFR. Pharmaceutical patent and generic brand drug: the legal tension between the exclusive right and the freedom to use. Curitiba: Juruá; 2013.

9. Marques W. Pharmaceutical patents in period post-WTO. 1ª ed. Curitiba: Appris; 2006.

10. Antunes MAS, Magalhães JL. Patenteamento e prospecção tecnológica no setor farmacêutico. Rio de Janeiro: Interciência: UFRJ, Departamento de Química; 2008.

11. Daumerie D. Report of the Scientific Working Group on Leprosy, 2002. Annex 8, WORKING PAPER: Elimination of leprosy as a public health problem - current status and challenges ahead, p. 62. Communicable Diseases. Geneva: World Health Organization; 2002. [cited 2020 Feb 04]. Available from: https://www.who. int/lep/resources/SWG04.pdf

12. Reis AS, Souza EA, Ferreira AF, Silva GV, Macedo SF, Araújo OD, Cruz JC, García GSM, Carneiro MAG, Barbosa JC, Ramos AN. Overlapping of new leprosy cases in household contact networks in two municipalities in North and Northeast Brazil, 2001-2014. Cad Saude Publica 2019; 35(10):e00014419.
13. Patent Cooperation Treaty (PCT). World Intellectual Property Organization (WIPO). [cited 2021 Jan 14]. Available from: https://www.wipo.int/pct/en/faqs/ faqs.html

14. Jannuzzi AHL, Vasconcellos AG. A study on the granting of drug patents in Brazil and its implications for the continued success of generic drug policy. In: $L a-$ tin-Ibero-American Congress on Technological Management, XV, 2013, Porto. Proceedings ...Lisboa: Center for Studies in Innovation, Technology and Development Policies; 2013. p. 3198-3214. [cited 2020 Feb 20]. Available from: http://www.altec2013.org/programme_pdf/635.pdf.

15. Jannuzzi AHL. Sui generis intellectual property rights systems in the pharmaceutical industry: a mechanism to encourage innovation for neglected diseases in Brazil? [Thesis]. Institute of Economics, Federal University of Rio de Janeiro, Rio de Janeiro; 2015. 299 p. [cited 2020 Feb 20]. Available from: http://www.ie.ufrj.br/images/ pos-graducao/pped/dissertacoes_e_teses/Anna_Hayde_.pdf.

16. Brazil. Law No 10.196, dated $14^{\text {th }}$ Feb 2001. Amends and adds provisions to Law No. 9,279, of May 14, 1996, which regulates rights and obligations related to industrial property, and makes other provisions. [cited 2021 Jan 04]. Available from: https://www.planalto.gov.br/ ccivil_03/leis/leis_2001/110196.htm

17. Meneghin RA, Paixão AEA. Elements for the elaboration of public patent policies dedicated to tuberculosis, $1^{\text {a }}$ ed. Vol. 1. Curitiba: Appris Editora; 2019.

18. Instituto Nacional da Propriedade Industrial (INPI). Resolution INPI No 239, dated June $04^{\text {th }} 2019$. Regulates the priority procedure of patents in the scope of DIRPA. Brasília: INPI; 2019.

19. Brazil. Law No 9.279 , dated $14^{\text {th }}$ May 1996. Provides rights and obligations related to industrial property. [cited 2020 Feb 19]. Available from: http://www.planalto.gov.br/ccivil_03/leis/L9279.htm

20. Instituto Nacional da Propriedade Industrial (INPI). Resolution INPI No 237, dated $28^{\text {th }}$ March 2019. Defines the Priority BR-IV Pilot Project. Brasília: INPI; 2019.

21. Instituto Nacional da Propriedade Industrial (INPI). Resolution INPI No 240, dated July $03^{\text {rd }} 2019$. Defines the preliminary requirement of examination pending invention patent application, without searches performed in Patent Bureaus in other countries, or in International or Local Organizations. Brasília: INPI; 2019.

22. Instituto Nacional da Propriedade Industrial (INPI). Resolution INPI No 241, dated July $03^{\text {rd }} 2019$. Defines the preliminary requirement of examination pending invention patent application, using the search results performed in Patent Bureaus in other countries, or in International or Local Organizations. Brasília: INPI; 2019.

Article submitted 22/10/2020

Approved 12/02/2021

Final version submitted 14/02/2021

Chief editors: Romeu Gomes, Antônio Augusto Moura da Silva 